\title{
Putting a Spin on Circulating Reference, or How to Rediscover the Scientific Subject
}

Jeff Kochan (jwkochan@gmail.com)

Zukunftskolleg, Box 216, University of Konstanz, 78457 Konstanz, Germany

\section{Abstract}

Bruno Latour claims to have shown that a Kantian model of knowledge, which he describes as seeking to unite a disembodied transcendental subject with an inaccessible thing-in-itself, is dramatically falsified by empirical studies of science in action. Instead, Latour puts central emphasis on scientific practice, and replaces this Kantian model with a model of "circulating reference." Unfortunately, Latour's alternative schematic leaves out the scientific subject. I repair this oversight through a simple mechanical procedure. By putting a slight spin on Latour's diagrammatic representation of his theory, I discover a new space for a post-Kantian scientific subject, a subject brilliantly described by Ludwik Fleck. The neglected subjectivities and ceaseless practices of science are thus re-united.

Key words: circulating reference; post-Kantian subjectivity; scientific practice; Bruno Latour; Ludwik Fleck.

\section{Introduction: It's Not Easy Being Two-Dimensional}

Boa Vista sounds like a wonderful place. I learned of it from Bruno Latour, who describes it beautifully in the second chapter of his 1999 book, Pandora's Hope: "Circulating Reference:

Sampling the Soil in the Amazon Forest." Yes, Boa Vista sits at the Amazon Forest. When I'd finished reading Latour's engaging tale of scientific adventure, I wandered into my kitchen, where a large map of the world hangs on the wall. There it was, in the northwest corner of Brazil, a small dot under the tip of my index finger - Boa Vista. How I wished to be there!

But maybe, somehow, I already was there. In his adventure story, Latour (1999, p. 65) writes that "the extension of the index finger always signals an access to reality even when it targets a mere piece of paper [...]. [T] hanks to inscriptions, we are able to oversee and control a situation in which we are submerged, we become superior to that which is greater than us." Alas, after reading Latour's lush account, my own experience of this small point under my finger tip felt pretty disappointing. Did this dot really give me access to the reality of Boa Vista? Did I, by spreading my hands across this world map, now oversee and control the situation in which I was submerged, my being-in-the-world? Sadly, no. I yearned to feel the gentle breeze of the savannah on my skin. I craved the warm camaraderie of Latour's charming scientific field unit. Instead, I stood alone with my finger stuck to a tiny speck on a 
faded map, enveloped in the miserably gray, wet weather of Switzerland in February. I did not feel superior.

I sought solace back in the pages of Latour's jungle tale. He admonished me to buck up: "Yes, scientists master the world, but only if the world comes to them in the form of two-dimensional, superposable, combinable inscriptions. It has always been the same story, ever since Thales stood at the foot of the Pyramids" (Latour 1999, p. 29). I tried to imagine myself as a vigorous player in this heroic history of two-dimensional mastery, lording over the world with my books and maps. But the bud had fallen from the vine. The three-dimensional rain battering the window of my study suddenly felt more powerful than Latour's entertaining pep talk.

\section{Science in Three Dimensions}

In this brief essay, I'd like to introduce a third dimension into Latour's two-dimensional account of scientific practice. My goal, like Latour's, is a philosophical one. His chapter is an exercise in field philosophy. Rather than cogitating endlessly in his comfortable Parisian armchair, Latour rose and flung himself into the rugged and remote jungles of northern Brazil, journeying as a participant observer with a small, international group of plant and soil scientists. He was not there as a social scientist, but as a philosopher. An ethnography of scientific culture was not Latour's brief, but the disinterested and merciless testing of an allegedly orthodox philosophical theory of "reference." The test was a success, and the result was negative. The theory was dramatically falsified by the overwhelming evidence of science in action. However, as luck would have it, Latour's philosophical field notes provided him with the material he needed to construct an empirically adequate alternative, his theory of "circulating reference."

Latour attributes the offending theory, just blown to bits in the Amazonian jungle, to the followers of Immanuel Kant. He provides a neat diagram depicting what he calls the "Kantian scenography" of this theory (Latour 1999, p. 72). Figure 1 closely approximates Latour's diagram. On the left, we find inaccessible things-in-themselves, on the right, a disembodied transcendental subject, which Latour also calls the categorising "forms of the human mind" (Latour 1999, p. 71). The two sides are meant to meet - somehow - in the middle, where the phenomena reside. According to Latour, his Amazonian field test demonstrates that the countless attempts over the generations to unravel the mystery of this "somehow" amount to nothing more than a fool's quest: "Our philosophical tradition has been mistaken in wanting to make phenomena the meeting point between things-in-themselves and categories of human understanding" (Latour 1999, p. 71). This may be so, depending on who "we" are. My own tradition, for one, didn't hit the skids with Kant, but includes a distinctly post- 
Kantian contingent. ${ }^{1}$ But such niceties will not delay Latour (1999, p. 72): in order for him to repair the debilitating mistake in "our" tradition, "a fifteen-day expedition is all that is required."

Latour's meticulous and penetrating expedition notes reveal that phenomena "are not found at the meeting point between things and the forms of the human mind; phenomena are what circulate all along the irreversible chain of transformations" characteristic of science in action (Latour 1999, p. 71). Hence, phenomena do not refer to inaccessible things-in-themselves, but only to each other. They circulate through a complex, multi-stage sequence of material practices, which Latour gathers under the labels "reduction" and "amplification." He provides another neat diagram depicting the scenography of his theory of circulating reference (Latour 1999, p. 72). Figure 2 closely approximates this second diagram.

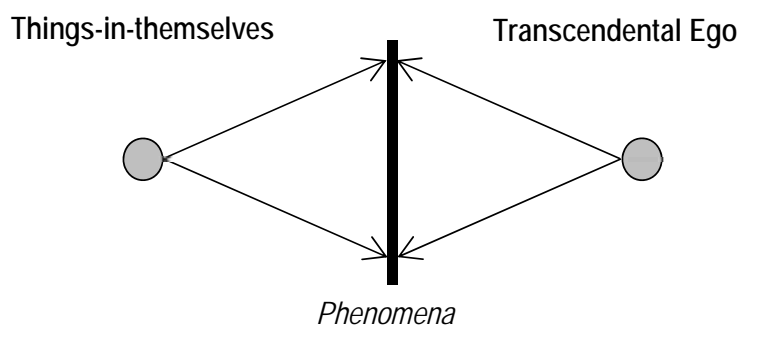

Figure 1 Latour's "Kantian scenography." Phenomena reside where inaccessible things and the disembodied subject meet. But where are the practices? (Based on Latour 1999, p. 72.)

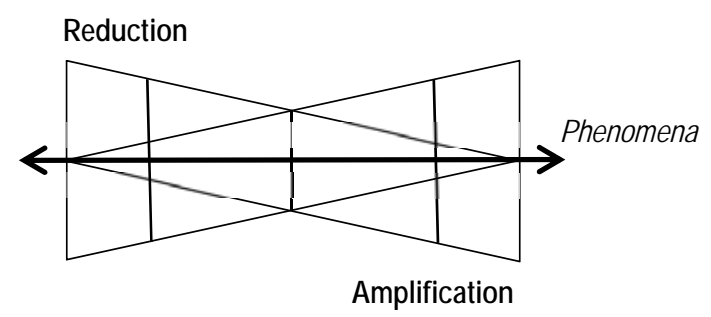

Figure 2 The Latourian scenography, depicting circulating reference. Phenomena circulate through a cascade of practices. But where is the subject? (Based on Latour 1999, p. 72.)

The principal question prompted by Latour's Kantian scenography is how a disembodied transcendental subject is supposed to gain epistemic access to definitively inaccessible things-inthemselves. If you think that this question makes no sense, then you have understood the root of Latour's problem. Where is the sense in trying to gain access to things which have already been defined as inaccessible? And, anyway, without a body, how is a subject supposed to do anything at all? Something seems to have gone wrong here. At the very least, Latour's Kantian scenography, as a depiction of scientific research, fails because it doesn't provide a place for scientific practice. Rather than recognising phenomena as constituted within complex fields of practice, where things and embodied subjects naturally interact, it tries instead to imagine them as the meeting point of two impossibly divided spheres, those two little, self-contained orbs depicted in Figure 1.

Latour will have nothing of this ridiculous scene. Having dramatically revealed its patent absurdity, he sweeps it off the table and erects his own alternative scenography in its place, the scenography of circulating reference. Figure 2 doesn't just include a place for scientific practice, it is comprised entirely of practices from end to end. Across this expansive plane, phenomena ceaselessly circulate in a complex choreography of science in action. There is no longer a question of how

\footnotetext{
${ }^{1}$ Among them Heidegger, from whom Latour has worked hard to distinguish himself; see Harman (2009), Kochan (2010), and Riis (2008).
} 
disembodied subjects hook up with inaccessible things, because the starting point for any question is now the recognition that things are always already swept up in an incessant current of referential scientific activity. Latour has replaced the apparently barren moonscape of Kantian epistemology with the lush and verdant jungle of his own theory of scientific practice.

But wait. Something is still askew. In his enthusiastic rush to clear the deck of science studies for the new superstructure of circulating reference, Latour has also jettisoned the scientific subject. The little, self-contained orb on the right side of Figure 1 has also been swept out to sea. But how can there be science without a subject? If phenomena are reduced and amplified in fields of practice, then who is doing the reducing and the amplifying, where are the practitioners? The Latourian scenography leaves these questions unanswered, and perhaps not unintentionally. Latour has, after all, told us that he "can't swallow much phenomenology [...] [and] never understood why consciousness was an important question anyway" (Crease et al. 2003, p. 21). As a result, he simply excludes the scientific subject from Figure 2. But this disappearance is less one of deletion than it is of submersion. What Roy Boyne calls an "indeterminate subjectivity," an ineluctable and inchoate being-in-the-world, is threatened with suffocation as Latour sinks it beneath the smooth surface of his alternative scenography (Boyne 2001, p. 34). The result is an impoverished picture of the scientific research process. With one dramatic turn, Latour has successfully removed some of the deepest difficulties plaguing his Kantian problematic, but clearly there is still more to be done. If we are to preserve a place for the post-Kantian subject in our practice-based studies of science, then we need to introduce one more turn after the Latourian turn.
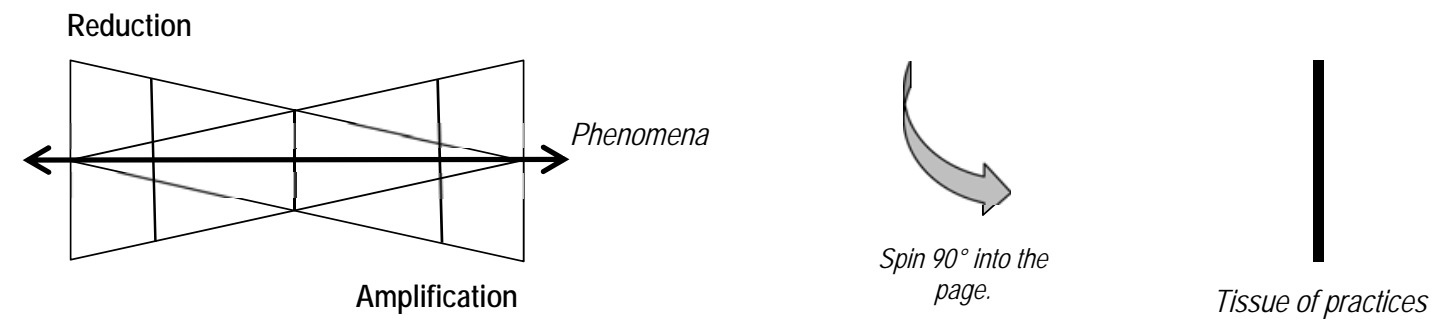

Figure 3 The Latourian scenography is spun $90^{\circ}$ into the page. We now view it from the edge. Nothing has been lost. Rather than being spread out on a two-dimensional plane, referential acts are now stacked in a rich three-dimensional tissue of practices. Phenomena ceaselessly circulate through this tissue. But the subject is still missing!

This turn is really just a bit of spin. You can see it happening in Figure 3. It's quite simple. Just spin the Latourian scenography $90^{\circ}$ into the page. Latour's two-dimensional account of science suddenly becomes three-dimensional! The lush scenography of scientific practice is still there. But instead of being spread out in two-dimensions across the surface of the page, it's now been spun up onto its edge. Nothing has gone missing. Everything is still there. But all of the complex, multi-stage sequences of material practice, so assiduously catalogued by Latour, are now viewed from the edge, as stacked up on top of each other so that they form a deep and rich tissue of practices, a tissue 
conveniently depicted in Figure 3 by a thick vertical line. Science has become three-dimensional once more!

\section{The Subject Is a Mess, Long Live the Subject}

Alas, viewed from the edge, the Latourian scenography now becomes a bit more difficult to decipher. But, if this should ever bother you, you could always just spin it back, so that everything is once more nicely laid out in two dimensions. In the meantime, putting Latour on edge has allowed us to free up some space. Space for what? For the subjectivities of scientific research, of course!

Now things become a bit delicate. Our mission is not to append the scientific subject to the tissue of practices, but to reattach the tissue of practices to the scientific subject. In order to do this, we need to perform a sensitive surgical operation. We need to take the deep and rich tissue of practices from Figure 3 and transplant it into Latour's Kantian scenography in Figure 1. Figure 4 depicts the procedure. The transformation is profound. Rather than the troubled collection of poor and underfed phenomena depicted in Figure 1, we now have a deep and rich tissue of practices in which robust and lively phenomena ceaselessly circulate - just what $\mathrm{La}($ doc)tour ordered!

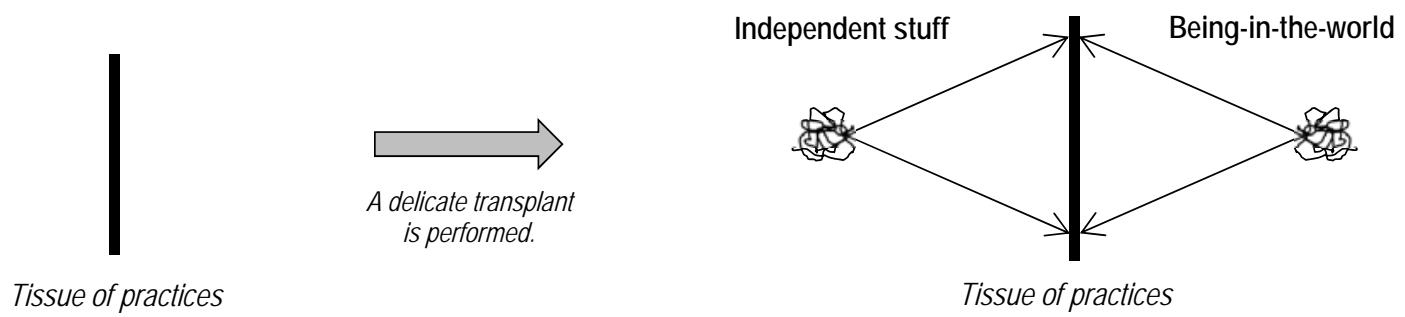

Figure 4 The living tissue of practices is carefully transplanted into Latour's Kantian scenography, radically transforming the patient. Being-in-theworld, the post-Kantian subject, combines with independent stuff in the tissue of practices, producing phenomena which now ceaselessly circulate through a three-dimensional landscape. Practice has been re-united with subjectivity.

Alas, the operation has now left our patient looking a bit piqued. The perfectly self-contained orbs in Figure 1 have now turned into confused and tangled messes. But that's just life, and the patient will have to adjust. Being a post-Kantian subject can be tough work: just think of onionallergic Susan Leigh Star, struggling for recognition and a bit of nourishment in the apparently universal but lamentably onion-normative world of McDonald's (Star 1991, pp. 34ff.).

On the left side of the tissue of practices in Figure 4, inaccessible things-in-themselves have transformed into independent but accessible stuff. On the right side, the disembodied transcendental subject has transformed into an unstructured but embodied field of first-person subjective experience, what phenomenologists sometimes call "being-in-the-world." Where in Figure 1 each side was depicted as a clear and distinct substance, in Figure 4 they have become chaotic and indefinite scribbles. The problem with Latour's Kantian scenography was that it presupposed the order and determinateness of subjectivity and stuff, rather than recognising that order and determinateness arise 
only when subjectivity and stuff unite in a rich tissue of practices. Before that, subjectivity subsists only as a delicate tangle of undisciplined personal experience, a being-in-the-world keen to find a home with others, perhaps even to become a "modest witness" within the community of science either in the gentlemanly sense of Steven Shapin and Simon Schaffer, or in the queer sense of Donna Haraway - or perhaps, instead, to splash out as an immodest scientific hero - as Latour depicts Pasteur. ${ }^{2}$ The post-Kantian subject is variously articulated within diverse fields of scientific activity, but it is not created ex nihilo by those activities. It subsists as a weak and indeterminate being-in-theworld, achieving strength and stability only within the deep tissue of practices, where it may find the means to develop a disciplined public identity in concert with an ever more disciplined conflux of scientific colleagues and stuff. ${ }^{3}$ Ludwik Fleck has described this as a process of "crystallisation."

\section{A Fleck of Good Sense}

Latour is a wonderful storyteller. His stories abound with charming and idiosyncratic characters, the author himself foremost among them. What a pity, then, that he left them out of his diagrammatic representation of science as circulating reference. Indeed, he didn't just leave them out, he left himself out, too. There is no room in Latour's diagram for the self, for ourselves, for $u s$ as fields of worldly existence, for our basic subjective experience of our own personal existence as being-in-the-world. ${ }^{4}$ How does the scientist experience herself as blindly grappling with a chaotic and tangled mess of independent stuff, as painstakingly coaxing that stuff out of its independent state and into a deep and rich tissue of practices where she can then slowly bring it to order, and so make clear and unequivocal sense of it?

Ludwik Fleck tells us how in his 1935 book, Genesis and Development of a Scientific Fact. He argues that phenomena capable of supporting reliable statements of fact first begin to take shape when "there is a signal of resistance in the chaotic initial thinking" of the researcher (Fleck 1979, p. 95). This signal comes only on the heels of considerable effort, sometimes extended over long periods of time: "in the complex confusion and chaos which he faces, [the scientist] must distinguish that which

\footnotetext{
${ }^{2}$ Shapin \& Schaffer (1985, p. 65); Haraway (1997, p. 23); Latour (1983).

${ }^{3}$ Hence I resist Lorraine Daston's and Peter Galison's claim that “[p]ost-Kantian subjectivity" presupposes a "unified self organized around the will," as well as their claim that "practices do not merely express a self; they [...] constitute it" (Daston \& Galison 2010, pp. 33, 199). In my view, postKantian subjectivity presupposes an unorganised and indefinite self, a self not so much constituted and expressed by practices as it is organised and specified by them.

${ }^{4}$ Yet Mark Elam suggests that Latour, the author, implicitly styles himself as "an untouchable subject [...] detached from, and not seriously embroiled in the different worlds he charts," a "privileged observer" blithely projecting a self-assured impartiality and innocence (Elam 1999, p. 3).
} 
obeys his will from that which arises spontaneously and opposes it" (Fleck 1979, p. 95). This "signal of resistance" announces that independent stuff and the experience of the researcher have finally encountered one another within the deep tissue of scientific practices. From there, the stuff is tirelessly coaxed, kneaded and shaped into a stable empirical phenomenon through a process which Latour places under the labels "reduction" and "amplification" and which Fleck calls "crystallisation." According to Fleck $(1979$, p. 53) the history of a research field "involves the progress of vague and indefinable concepts which are about to crystallize." 5

Yet, whereas the Latourian scenography provides an only two-dimensional account of this process, Fleck allows us to view it in three dimensions, as a phenomenological landscape inhabited by a scientific subject who slowly emerges from the chaos and confusion of its initial perceptions by pursuing fact-based knowledge of phenomena. Furthermore, in this landscape, we see not only how phenomena circulate through a cascade of transformations within an established tissue of practices, but also how a research community meticulously clarifies and brings under control independent and unmanageable stuff by resolutely drawing it ever deeper into a growing tissue of material associations. Through these efforts to crystallise phenomena, "primitive pre-ideas often lead continuously to modern scientific concepts" (Fleck 1979, p. 100).

Fleck brilliantly supports his epistemological considerations with a detailed history of syphilis research. He observes that, at the end of the fifteenth century, the diagnosis of syphilis disappeared into what he calls "an undifferentiated and confused mass of information" and a "primitive jumble" (Fleck 1979, p. 1). It would take four centuries before the modern scientific concept of syphilis crystallised from out of this confused and jumbled diagnostic experience. Fleck (1979, p. 23) describes the process like this: "We have described a hazy idea of syphilitic changes in the blood and shown that this idea existed centuries before scientific proof was available. Emerging from a chaotic mixture of ideas, it developed over many epochs, becoming more and more substantial and precise." This summarises a stunning phenomenological history of emergent scientific events within an evolving tissue of practices. A vague and undifferentiated disease entity encounters a correspondingly confused and uncertain scientific subjectivity. Over centuries, they become increasingly entangled in a deep tissue of developing diagnostic procedures, slowly becoming more and more distinct, more and more nuanced and clear, more and more definite and precise, as some avenues of explanation are strengthened and refined while others are blocked off and forgotten. Fleck gives us an outstanding three-dimensional description of the scientific research process.

\footnotetext{
${ }^{5}$ For a more detailed discussion of this process, see Kochan (forthcoming).
} 


\section{Conclusion: The Social Coordination of Scientific Subjectivity}

Two amicable and highly skilled soil scientists stand side-by-side in the jungle near Boa Vista (Latour 1999, pp. 62f.). They are "earth tasting." They each carefully spit on a clump of soil cradled in the palm of their hands. They then knead the dampened clump with the fingers of the other hand. They're trying to determine the texture of the soil. If it's more clay-like, then it originally comes from the forest. If it's more sand-like, then it originally comes from the savannah.

"Sandy-clay or clayey-sand?"

"No, I would say clayey, sandy, no sandy-clay."

"Wait, mold it a bit more, give it some time."

"Okay, yes, let's say between sandy-clay and clayey-sand."

A third scientist makes a conscientious note of this subtle and coordinated judgement in her field journal. Latour (1999, p. 63) writes that "[1]acking any kind of gauge, Armand and René rely on a back-and-forth discussion of their judgments of taste, as my father would do when he tasted his Corton wines."

The message is clear and exciting: scientific perception is like wine-tasting! The scientist and the vintner are like two peas in a pod of extraordinarily refined subjective experience. They possess what Michael Polanyi called "personal knowledge": "[t]o become an expert wine-taster, to acquire a knowledge of innumerable different blends of tea or to be trained as a medical diagnostician, you must go through a long course of experience under the guidance of a master" (Polanyi 1958, p. 54). This interpersonal education of the senses leads to the formation of what Steven Shapin calls "taste communities": these communities "coalesce around practices [...] that refer to mutually accessible external properties as the causes of internal states" (Shapin 2012, p. 178). ${ }^{6}$

When Armand and René practice earth tasting, they are coordinating their internal subjective experiences using the mutually accessible external properties of spittle and soil. Whether this process of coordination involves two experts negotiating an agreement, or a student calibrating her experiences to those of her teacher, it is an eminently intersubjective process, a process which necessarily unfolds deep within the rich tissue of practices depicted in Figure 4. Both Latour's Kantian scenography, as well as his own alternative scenography, failed to capture this important dimension of scientific research. Luckily, these shortcomings were easily repaired. All it took was a slight spin of the latter, followed by its delicate transplantation into the former. Latour required a fifteen-day expedition in northern Amazonia to resolve a problem in his Kantian scenography. From the cozy confines of my provincial armchair, I resolved a problem in the Latourian scenography in less than fifteen seconds. I rediscovered the scientific subject swept overboard by Latour's two-dimensional model of science as circulating reference. Quite frankly, I'd have rather gone on the expedition. But when funds are

\footnotetext{
${ }^{6}$ For more on Polanyi, Shapin, and taste communities see Kochan (2013).
} 
limited one must sometimes make do with the inexpensive resources of one's own subjective imagination, publicly circulating the results in the anxious hope that others may receive them as the sensible basis for a nice bit of social co-ordination.

\section{Acknowledgements}

For their helpful comments on an earlier draft, I thank David Bloor, Estheranna Stäuble, and an anonymous referee.

\section{References}

Boyne, R. (2001). Subject, Society and Culture. London: SAGE.

Crease, R., Ihde, D., Bruun Jensen, C. \& Selinger, E. (2003). Interview with Bruno Latour. In D. Ihde \& E. Selinger (Eds.), Chasing Technoscience: Matrix for Materiality (pp. 15-26). Bloomington: Indiana University Press).

Daston, L. \& Galison, P. (2010). Objectivity. New York: Zone Books.

Elam, M. (1999). Living Dangerously with Bruno Latour in a Hybrid World. Theory, Culture \& Society, 16(4), 1-24.

Fleck, L. (1979). Genesis and Development of a Scientific Fact (F. Bradley \& T. J. Trenn, Trans.) (T. J. Trenn \& R. K. Merton, Eds.). Chicago: University of Chicago Press. (First published 1935)

Haraway, D. J. (1997).Modest_Witness@Second_Millenium.FemaleMan@_Meets_OncoMouse ${ }^{\mathrm{TM}}$ : Feminism and Technoscience. London: Routledge.

Harman, G. (2009). Prince of Networks: Bruno Latour and Metaphysics. Melbourne: re.press.

Kochan, J. (forthcoming). Circles of Scientific Practice: Regressus, Mathēsis, Denkstil. In D. Ginev \& E. O. Graf (Eds.), Hermeneutic Aspects of the Constitution of Scientific Facts. Zürich: Collegium Helveticum.

Kochan, J. (2013). Subjectivity and Emotion in Scientific Research. Studies in History and Philosophy of Science, 44(3), 354-362.

Kochan, J. (2010). Latour's Heidegger. Social Studies of Science, 40(4), 579-598.

Latour, B. (1999). Pandora's Hope: Essays on the Reality of Science Studies. Cambridge MA: Harvard University Press.

Latour, B. (1983). Give Me a Laboratory and I Will Raise the World. In K. D. Knorr-Cetina \& M. Mulkay (Eds.), Science Observed: Perspectives on the Social Study of Science (pp. 141-170). London: SAGE.

Polanyi, M. (1958). Personal Knowledge: Toward a Post-Critical Philosophy. Chicago: University of Chicago Press.

Riis, S. (2008), The Symmetry Between Bruno Latour and Martin Heidegger: The Technique of Turning a Police Officer into a Speed Bump. Social Studies of Science, 38(2), 285-301.

Shapin, S. (2012). The Sciences of Subjectivity. Social Studies of Science, 42(2), 170-184.

Shapin, S. \& Schaffer, S. (1985). Leviathan and the Air-Pump: Hobbes, Boyle, and the Experimental Life. Princeton: Princeton University Press.

Star, S. L. (1991). Power, Technology and the Phenomenology of Conventions: On Being Allergic to Onions. In J. Law (Ed.), A Sociology of Monsters: Essays on Power, Technology and Domination (pp. 26-56). London: Routledge. 